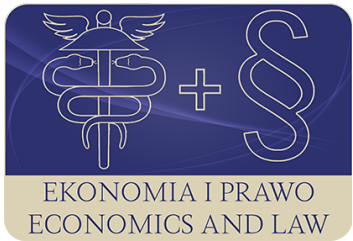

EKONOMIA I PRAWO. ECONOMICS AND LAW

Volume 17, Issue 1, March 2018

p-ISSN 1898-2255, e-ISSN 2392-1625

www.economicsandlaw.pl

ECONOMICS AND LAW

ORIGINAL ARTICLE

received 13.06.2017; revised 01.12.2017; accepted 31.03.2018

Citation: Limański, A., Popławska, Ż., Drabik, I. (2018). Marketing information system and risk reduction in managing a company on foreign markets. Ekonomia i Prawo. Ecomomics and Law, 17(1):

43-55. doi:10.12775/EiP.2018.004.

\title{
Marketing information system and risk reduction in managing a company on foreign markets
}

\author{
ANDRZEJ LIMAŃSKI \\ corresponding author \\ University of Silesia, Faculty of Pedagogy and Psychology, Department of Management, \\ ul. Grażyńskiego 53, 40-126 Katowice, Poland \\ ๑andrzejlimanski@interia.pl \\ ŻANNA POPEAWSKA \\ Lviv Polytechnic National University, Institute of Administration and Postgraduate Education, \\ Department of Theoretical and Applied Economics, Ukraine \\ Rzeszów University of Technology, Faculty of Management, Department of Marketing, Poland \\ $\square$ zhannapoplawska@gmail.com

\section{IRENEUSZ DRABIK} \\ Pedagogical University of Krakow, Faculty of Political Science, Institute of Law, Administration and \\ Economics, Department of Self-Government and Management, Poland \\ 曰i.drabik@wp.pl

\begin{abstract}
Motivation: The need to develop marketing information systems results from the generally accepted need act according to marketing concept. When defined as a specific type of management information, marketing information refers to any kind of data that can be used in the process of marketing management in order to attenuate the uncertainty of decisions undertaken in the context of strategic marketing and operational marketing. The dynamic character of market processes and phenomena causes that decision-making always entails a certain dose of risk. Risk reduction is possible, for instance, by means of deploying relevant marketing information. One may, therefore, say that a role of information in a decision-making process could be perceived in terms of both uncertainty reduction and rendering undertaken decisions a privilege of correctness understood a priori.
\end{abstract}


Aim: Any expansion beyond the scope of domestic market and searching for competitive advantages in the diversified international business environments are necessitated by taking decisions which involve greater risk than routine decisions based on experiences derived from the corporation's domestic market. Likewise, decision-making process require a more profound informational support when they refer to international markets. By placing an emphasis on the sub-system of marketing research undertaken in a multicultural business environment, this paper aims to categorize and provide an in-depth insight into theoretical bases of marketing information systems with regard to companies functioning on foreign markets. The text elaborates upon the role of information in marketing management as well as upon selected approaches to the formation of marketing information systems. Moreover, the significance of international marketing research and its role in the process of corporate internationalization are explained. Likewise, basic forms of organization with regard to international marketing research are also characterized and explained from a perspective of involved spatial variables.

Results: Globalization processes and the increase in the internationalization of enterprises pave the way for the development of marketing information systems which are utilized by contemporary business ventures seeking to internationalize their operations. Hence, one may postulate that the development of conceptualizations referring to international and global marketing is a motivating factor leading to the increase in the significance of well-constructed systems of marketing information with a special emphasis placed on the subsystem of marketing research. At this point, one has to bear in mind the international marketing research cannot be treated simply as an extension of domestic studies. When investigating international business environment, one is in a position to take a plethora of specific methodological problems into account at all stages of research procedures. The fundamental problem of international marketing research, which may be conceived as a context for further research, is equivalence of studies on diverse foreign markets and diverse cultures.

Keywords: international business; international marketing; risk; marketing information system JEL: D81; F23; L20; M31

\section{Introduction}

Being specifically focused on the subsystem of marketing research, this article aims to systematize knowledge with respect to theoretical foundations of marketing information systems and their role for enterprises that function on foreign markets. Having relevant data at one's disposal is a necessary factor for choosing foreign markets and appropriate action strategies, decision-taking with respect to standardization or adaptation to particular markets, and for other operations performed on international markets. An increase in uncertainty experienced with reference to the international business environment paves the way for a comparable increase in risk, as it is perceived by managers who are in a position to take strategic or tactical decisions (Anderson, 2014; Andersen \& Schroder, 2010; Chapman, 2012; Drabik, 2016; Urbanowska-Sojkin, 2013). The same applies to businesses which have just initiated internationalization processes (i.e. by means of taking up direct and indirect export), enterprises which are developing overseas operations (i.e. capital and non-capital 
cooperation, direct foreign investments), as well as to companies that have already entered the phase of making their strategies more global (Duliniec, 2009, p. 143; Schroeder et al., 2013, pp. 11-15; White \& Fan, 2006).

When presented in a detail, the aims of this article comprise (1) outlining a role of information in management, and a characteristic of selected approaches to the formation of marketing information systems; (2) explaining the significance of international management research and their role in business internationalization processes; (3) identification and characteristic of basic types of international marketing research as differentiated by their spatial scope (i.e. independent, sequential and simultaneous research). Since an ability to compare study results across markets and cultures is indispensable for making relevant decisions in international management, the concluding remarks put great stress on the role and significance of equivalence of various types of research conducted in international business settings (i.e. equivalence of research object, equivalence of measurement, equivalence of sampling, equivalence of direct research processes); namely, studies taken up with regard to differentiated markets and cultures.

\section{Literature review}

Various empirical researches on enterprise internationalization and its effects have been conducted since the 60s of the last century. First such results were presented in the study of S.H. Hymer in 1960. They were used, among other things, to establish whether international companies are more efficient than business entities operating solely on domestic markets (Verbeke \& Brugman, 2009, p. 266).

Company internationalization and foreign market research have increasingly been analyzed in Polish specialized literature. Recently there have been a number of publications based on empirical studies on activity internalization of Polish companies in foreign environment.

The issue of investment activity of Polish companies was raised in the study by W. Karaszewski (2013). The main goal of his research was to analyze the change of scale and structure in direct foreign investment by Polish companies (BIZ), to identify the importance of capital allocation by BIZ from among other competitiveness factors of domestic enterprises, to identify the impact of BIZ on risk that investing entities take and by means of which an attempt to formulate a risk factor model can be made, as well as to identify BIZ effectiveness evaluation methods applied by Polish companies.

The problem of the so called early internationalization of Polish enterprises was addressed by M. Jarosiński (2013). By his empirical research he was trying to find out whether any of the Polish companies operating and expanding on foreign markets reflects the early model of internationalization.

M. K. Witek-Hajduk (2010) in her work based on empirical research describes an analysis of selected factors determining internationalization strategies 
adopted by Polish enterprises on the EU markets, real strategies adopted and any changes in this respect.

K. Wach (2012) in turn, presented an empirical verification of the impact of macroeconomic Europeanisation processes on the level of development and Europeanisation of Polish companies after Poland accessed the EU.

With reference to the above mentioned works the results of research of J. W. Wiktor and P. Chlipała (2012) into internationalization of marketing strategies of Polish companies as well as research by G. Karasiewicz (2013) are also of great interest.

The role and significance of marketing research in internationalization strategy was also discussed by A. Żbikowska (2013, p. 27). As she writes, conducting marketing research should be an indispensable set piece when planning and implementing marketing activity strategies on foreign markets.

A comprehensive approach to the problem of how marketing information systems should be organized is postulated by K. Mazurek-Łopacinska (2005, p. 38). In this context, marketing information system is a foundation of marketing decision-making, and it refers to durable reciprocally organized structures comprising personnel, technical equipment, procedures used to gather, sort, analyze and evaluate accurate data taken from internal and external sources. The subsystem of record-keeping and statistical report aims to gather operational information concerning the current operations undertaken by a given enterprise (e.g. monthly sales reports, sales assessments, information concerning product recalls and complaints). The subsystem of marketing intelligence aims to gather data concerning the company's business environment and its changes (e.g. information concerning clients, review of specialized periodicals, media content analysis, taking part in congresses or fairs). The subsystem of marketing research aims to provide solutions to specific decision-making problems. The modelling subsystem, in turn, helps us to process the gathered information by means of statistical and econometric methods and tools. It also comprises a databank of decision-making models and analytical models, as well as relevant computer software.

\section{Methods}

Methodologically speaking, the article is based upon a critical analysis of publications in the field of management and marketing. Such approach seems to be justified due to the main aim of the article, which is an attempt to systematize and broaden our knowledge of theoretical foundations of marketing information systems in companies operating on foreign markets. Critical literature on the topic has made it possible to select basic recommendations that Polish companies seeking to internationalize their operations should put into practice. What matters today is not only the awareness of the role and significance of a company's marketing information system in general but the ability to dif- 
ferentiate between the specificity of market research of foreign character and research carried out on the domestic market.

\section{Foreign markets research in the marketing information system}

Diversified enterprises are motivated by a necessity to meet expectations expressed by purchasers who are willing to show their needs and preferences on the market. The significance of marketing information systems rises with the increase in the role of marketing for the totality of management processes. Information is endowed with a number of applications for management, which can be divided into three distinct categories: planning, analyzing, controlling. When observed in the context of planning, marketing information facilitates goal definition, predicting the results of strategic alternatives, or characterization of budgets which are adequate to efforts made in the past. Information serves as a basis for analyses undertaken with respect to factors and determinants of marketing activities. The process of analysis comprises identification of relevant needs, market segmentation, estimation of market potential, and sales planning. In the context of control exerted with reference to marketing actions, information serves as a tool rendering making comparisons between the said actions and their results, competitors' activities, or budgets as well as economic results achieved in previous years (Mazurek-Łopacińska, 2005, p. 37).

The construction and implementation of an efficient marketing information system is rendered possible by the following characteristics of implemented problem-solving solutions (Kaczmarczyk, 2003, pp. 24-25):

- The system should not deliver excessive or redundant information. If otherwise, the system suffers from a wrongly projected network of information exchange and the lack of cooperation with relevant decision-makers. The relevant data should be carefully estimated and aggregated according to information-related needs.

- Both users and data providers should become aware of undertaken decisions and be informed when it comes to information-related needs appearing at every stage of decision-making processes. Both parties are in a position to understand and recognize the scope of shared interests.

- The delivery of data within the marketing information system is not sufficient. Users often expect help when it comes to decision-making situations, which is the factor facilitating experiential learning with reference to taking risky decisions.

- Users should understand and accept the marketing information system, and consider it as their own system. Such a belief is a factor fostering cooperation and attenuation of anxieties associated with taking risk-laden decisions.

- Marketing information systems are always vital elements of enterprises whereas marketing researches could be successfully outsourced. Such re- 
searches are more and more frequently considered as a part of the marketing information system. Moreover, the implementation of a marketing information system should be supported by senior management.

A specific place in the marketing information system is reserved for marketing research whose application may provide us with information concerning a plenitude of aspects typical of market-oriented organizations. Marketing research could be defined as an objective process designed in order to gather, process and present information necessary for marketing decision-making. Such a conceptualization comprises the following elements (Kędzior \& Karcz, 2007, p. 21):

- the systemic character of marketing research results from a tendency to perceive it as an integral subsystem of a given marketing information system;

- objectivity means that marketing research is based upon common standards for scholarly objectivism which is achieved by using scholarly methods of data processing and interpretation;

- processual approach enables to treat research as a series of interrelated, repetitive procedures (i.e. stages).

Marketing research can be useful on all stages of a decision-making process. Acquired information are helpful when it comes to recognizing decision-making situations and choosing relevant action strategies. Yet, a majority of marketing-related decisions do not require a substantial input of information taken from marketing research. Such decisions are repetitive, and a manager's experience and commonsensical attitude seem sufficient for their taking. However, information gathered by means of marketing research are indispensable when managers face decision-making problems in new situations.

M.R. Czinkota and I.A. Ronkainen observe that any marketing research of domestic market differ significantly from research focused upon international markets. The differences result from the following factors (Wiktor et al., 2008, pp. 156-157):

- enterprises seeking foreign expansion face new factors of business environment which do not have to be taken into consideration when a company is engaged solely in operations performed on the domestic market (i.e. duties and tariffs, foreign currencies, international business documentation);

- the circumstances of domestic market are dissimilar in comparison to those typical of foreign markets. As a result, managers have to get accustomed to new culture, legal system, differences in social structure. Many principles and guidelines, which are operational on the domestic markets, must by invented from a scratch;

- foreign market expansion entails dealing with a bigger number of competitors than it is required on a domestic market. 


\section{The scope and types of marketing research of foreign markets}

The scope of useful information needed to make decisions on foreign markets is far more comprehensive than in the case of domestic markets and it refers mostly to assumptions concerning initiating or expanding international business operations, choosing specific foreign markets, choosing ways of entering the foreign markets, establishing marketing program and its implementation (Albaum et al., 2016) (table 1). First and foremost, marketing research should deliver data concerning the enterprise's developmental perspectives on foreign markets (i.e. dangers and opportunities related to foreign business operations). Next, one must specify a number and hierarchy of serviced markets (i.e. exploring effectiveness of all possible forms of internalization), taking their actual and future potential, estimated costs and profits, estimation of competitive situation and operational risks into account. When marketing programs are being implemented, it is important to recognize - apart from investigating purchasers' behavior, intensity of competition, available means and channels of distribution and promotion - potential guidelines for the standardization of marketing actions. A comprehensive scope of data is indispensable for taking decisions concerning the implementation and supervision of marketing programs, as it is evident in the case of assessing the effectivity of various organizational solutions (e.g. establishing foreign subsidiaries and branches, centralization or decentralization of certain marketing-related functions) (Limański \& Drabik, 2010, pp. 186-187).

An increase in the intensity of internationalization paves the way for the delineation of spatial range of international marketing research. As a consequence, three types of international marketing research have been differentiated $(\mathrm{Ku}-$ mar, 2000, pp. 18-21):

- independent marketing research which is organized separately in countries and often financed by the company's foreign subsidiaries;

- sequential marketing research first conducted on one or several foreign markets and later on extended to other markets;

- simultaneous international marketing research is based upon conducting research simultaneously on different foreign markets.

A huge proportion of problems associated with conducting marketing research on foreign markets is a matter of cultural differences taking place among particular countries. That is why, both projecting and conducting of marketing research require having background knowledge concerning the given cultural environment. When applied to different cultures, marketing research could be conducted with regard to the 'emic' or 'etic' approach.

The emic approach indicates that encountered phenomena must be explained and interpreted in the target culture's context; namely, from within a given cultural system. Researches are limited to one culture only, and the assumed rules and research criteria are related to the internal cultural characteristics. 
Hence, research tools have to be adjusted to meanings and perceptions typical of the target culture. In this sense, behaviors and attitudes are always manifested in an unique way and, consequently, inter-cultural studies are simply impossible to implement. This type of approach is typical of qualitative research.

The etic approach has a different character and takes the universal character of cultural phenomena into account. Since, these phenomena are similar in diverse cultures, they can be studied 'from the outside'. In this context, phenomena typical of a target culture can be studied and understood by analogy to other cultures. Researches are implemented with regard to a variety of cultures, and the acquired criteria are universal in scope, which renders the use of standardized research tools possible. This type of approach is typical mostly of quantitative studies, but it is associated with problems that are not limited to one culture (Duliniec, 2009, pp. 145-146; Karcz, 2004, pp. 141-145; Kędzior \& Karcz, 2007, pp. 53-54; Limański \& Drabik, 2010, pp. 199-200; Wiktor et. al., 2008, pp. 177-178).

\section{Conclusion}

The fundamental problem of international marketing research, which may be conceived as a context for further research, is equivalence of studies on diverse foreign markets and diverse cultures. Overcoming cultural differences renders possible a comparison of study results taking place in many different countries and, in the long run, taking relevant decisions. The table 2. presents categories of equivalence as they refer to international marketing research.

Significant difficulties may appear at the stage of providing definitions and necessary conceptualizations for research aims and research problems. Cultural diversity results in discrepancies in the way notions related to social and economic functioning are understood across a number of countries. Conceptual equivalence is also a problem that calls for relevant solutions, because the term refers to the distribution of meaning and related attitudinal and behavioral responses across cultures. Functional equivalence, in turn, refers to a notion's functional distribution across diversified cultural settings. One of the best strategies to identify functional equivalence is studying social determinants typical of a given type of activity and, later on, observing its significance for the relevant social groups. The notion of categorical equivalence refers to our ability to assume unified criteria according to which individuals are subsumed within larger groups or categories (e.g. different criteria are deployed for delineating age ranges in statistical studies across countries).

A next stage of international marketing research is ensuring that measurement techniques are equivalent. Hence, one is in a position to take care of calibration equivalence (i.e. units of measurement), which means that undertaken actions must refer to the same monetary, distance or weight units. Taking a good care of metric equivalence with reference to verbal measurement scales is equally critical (i.e. different languages are characterized by distinct 
ways of providing comparative and superlative adjectival forms). When it comes to preparing research tools for foreign markets, one comes translation equivalence across, term which refers to the quality of relevant translations.

An important element of international marketing studies is a selection of relevant research samples which render the generalization of study results and their inter-cultural comparisons possible. When related to the selected sampling methodology, the notion of equivalence refers to the selection of such respondents who may constitute a target group perceived form a perspective of a given enterprise. The equivalence of research population gives rise to difficulties in getting well-defined respondent lists referring to populations in researched countries. Such lists may be outdated or incomparable across societies due to having been prepared on a basis of different criteria (i.e. age, income or education). International marketing research is also problematized by ensuring the equivalence of sampling methodology which — when properly undertaken - renders the internationalization of studies possible.

The procedures of international marketing research are necessitated by providing equivalent strategies for collecting and aggregating data. In this case, one must head towards uniformity in the field of research techniques. Contextual equivalence refers to a situation in which information is collected. At this point, one has to remember that respondents in different cultures are characterized by distinct motivations to take part in surveys, to express their opinions or attitudes, and to behave properly when answering the questionnaire questions. Temporal equivalence in concerned with a problem of outdated information. Apart of an obvious case of 'ageing data', one has to take notice that the said process is not identical across countries or cultures (i.e. information concerning prices become outdate significantly faster in economies characterized by high inflation rate). Moreover, temporal equivalence refers to differences in economic or technological developmental level that varies across countries. Such developmental differences render making comprehensive comparisons difficult because the formation of certain processes or phenomena in a developed country must be compared to a historical situation taking place several or several dozens of years earlier in order to match a situation experienced by a country of lower level of development (Karcz, 2004, pp. 149-170; 2005, pp. 223-233; Kędzior \& Karcz, 2007, pp. 54-60; Limański \& Drabik, 2010, pp. 200-205; Wiktor et.al., 2008, pp. 177-181).

\section{References}

Albaum, G.S., Duerr, E., \& Josiassen, A. (2016). International marketing and export management. Harlow: Pearson.

Andersen, T.J., \& Schroder, P.W. (2010). Strategic risk management practice. How to deal effectively with major corporate exposures. London: Cambridge University Press. doi:10.1017/CBO9780511816017. 
Anderson, E.J. (2014). Business risk management. Models and analysis. Chichester: Wiley. doi:10.1002/9781118749388.

Chapman, R.J. (2012). Simple tools and techniques for enterprise risk management. Second edition. Chichester: Wiley. doi:10.1002/9781118467206.chl8.

Drabik, I. (2016). Ryzyko internacjonalizacji przedsiębiorstwa w warunkach turbulencji otoczenia. Acta Universitatis Nicolai Copernici. Ekonomia, 47(1). doi:10.12775/AUNC_ECON.2016.005.

Duliniec, E. (2009). Marketing międzynarodowy. Warszawa: PWE.

Hollensen, S. (2007). Global marketing. A decision-oriented approach. Harlow: Prentice Hall.

Jarosiński, M. (2013). Procesy i modele internacjonalizacji polskich przedsiębiorstw. Warszawa: Oficyna Wydawnicza SGH.

Kaczmarczyk, S. (2003). Badania marketingowe. Metody i techniki. Warszawa: PWE.

Karasiewicz, G. (2013). Marketingowe strategie internacjonalizacji polskich przedsiębiorstw. Warszawa: Wolters Kluwer Business.

Karaszewski, W. (Ed.). (2013). Aktywność inwestycyjna polskich przedsiębiorstw za granica. Czynniki i skutki. Warszawa: PWE.

Karcz, K. (2004). Międzynarodowe badania marketingowe. Uwarunkowania kulturowe. Warszawa: PWE.

Karcz, K. (2005). Międzynarodowe badania oparte na źródłach pierwotnych — podejście kulturowe. In K. Mazurek-Łopacińska (Ed.), Badania marketingowe. Teoria i praktyka. Warszawa: WN PWN.

Kędzior, Z., \& Karcz, K. (2007). Badania marketingowe w praktyce. Warszawa: PWE.

Kumar, V. (2000). International marketing research. New York: Prentice Hall. Limański, A., \& Drabik, I. (2010). Marketing międzynarodowy. Warszawa: Difin. Mazurek-Łopacińska, K. (2005). System informacji marketingowej i organizacja badań. In K. Mazurek-Łopacińska (Ed.), Badania marketingowe. Teoria i praktyka. Warszawa: WN PWN.

Schroeder, J., Bartosik-Purgat, M., \& Mruk, H. (2013). Międzynarodowe badania marketingowe. Poznań: Wydawnictwo UE w Poznaniu.

Urbanowska-Sojkin, E. (2013). Ryzyko w wyborach strategicznych $w$ przedsiębiorstwach. Warszawa: PWE.

Verbeke, A., \& Brugman, P. (2009). Triple-testing the quality of multinationality-performance research. An internationalization theory perspective. International Business Review, 18(3). doi:10.1016/j.ibusrev.2009.01.005.

Wach, K. (2012). Europeizacja matych i średnich przedsiębiorstw. Rozwój przez umiędzynarodowienie. Warszawa: PWN.

White, C., \& Fan, M. (2006). Risk and foreign direct investment. New York: Palgrave MacMillan. doi:10.1057/9780230624832.

Wiktor, J. W., \& Chlipała, P. (Ed.). (2012). Strategie marketingowe polskich przedsiębiorstw na rynkach międzynarodowych. Warszawa: PWE. 
Wiktor, J.W., Oczkowska, R., \& Żbikowska, A. (2008). Marketing międzynarodowy. Zarys problematyki. Warszawa: PWE.

Witek-Hajduk, M.K. (2010). Strategie internacjonalizacji polskich przedsiębiorstw w warunkach akcesji Polski do Unii Europejskiej. Warszawa: Oficyna Wydawnicza SGH.

Żbikowska, A. (2013). Uwarunkowania ekspansji eksportowej polskich przedsiębiorstw. Marketing i Rynek, 2.

\section{Acknowledgements}

Author contributions: authors have given an approval to the final version of the article. Authors contributed to this work equally.

Funding: this research was fully funded by the authors. 


\section{Appendix}

Table 1.

Information-related foundations of decision-making in the context of expansion to foreign markets

\begin{tabular}{|c|c|}
\hline Decision type & Required data \\
\hline \multirow{4}{*}{$\begin{array}{l}\text { taking up the internationalization } \\
\text { of an enterprise }\end{array}$} & - demand for products on foreign markets \\
\hline & - possibilities for internationalization \\
\hline & $\begin{array}{l}\text { - competitiveness of an enterprise on a given market with reference to domes- } \\
\text { tic and international competitors }\end{array}$ \\
\hline & - benefits of internationalization as compared to domestic business operations \\
\hline \multirow{5}{*}{ choice of foreign markets } & - market potential of countries (or regions) \\
\hline & - market competition \\
\hline & - political risk \\
\hline & - barriers to foreign trade \\
\hline & - 'cultural distance' to potential markets \\
\hline \multirow{6}{*}{ ways to enter foreign markets } & - product specificity and the intensity of its diversification \\
\hline & - market size \\
\hline & - behaviors of local commodity brokers \\
\hline & - competition strategies \\
\hline & - transportation expenses \\
\hline & - legal regulations \\
\hline \multirow{4}{*}{$\begin{array}{l}\text { formulation of a marketing } \\
\text { program }\end{array}$} & - costumers' behaviors \\
\hline & - competition-oriented practices \\
\hline & - availability of distribution channels \\
\hline & - strategies for marketing communication, availability of various media \\
\hline \multirow{4}{*}{$\begin{array}{l}\text { implementation and supervision } \\
\text { of a marketing program }\end{array}$} & - culture specific negotiation styles \\
\hline & $\begin{array}{l}\text { - sales volume of product with reference to types of product range, purchasers, } \\
\text { countries (regions) }\end{array}$ \\
\hline & - market share \\
\hline & - marketing-related expenses \\
\hline
\end{tabular}

Source: Own preparation based on Hollensen (2007, p. 156). 
Table 2.

Categories of equivalence in international marketing research

\begin{tabular}{ll}
\hline \multicolumn{1}{c}{ Category } & \multicolumn{1}{c}{ Types of equivalence } \\
\hline equivalence of research object & - conceptual equivalence \\
& - functional equivalence \\
& - categorical equivalence \\
\hline equivalence of measurement & - calibration equivalence \\
& - metric equivalence \\
& - translation equivalence \\
\hline equivalence of sampling & - equivalence of sampling units \\
& - equivalence of research population \\
\hline & - equivalence of sampling methodology \\
\hline & - equivalence of data collection \\
& - contextual equivalence \\
\end{tabular}

Source: Own preparation based on Karcz (2004, p. 150). 
